\title{
Seed predation food web, nutrient availability, and impact on the seed germination of Senegalia tenuifolia (Fabaceae)
}

\author{
Juliana Tuller*, Elisa L. de Paula, Laís F. Maia, Raphael A. Moraes \& Lucas D. B. Faria \\ Universidade Federal de Lavras. Campus Universitário, Caixa Postal 3037, CEP 37200-000, Lavras-MG, Brazil; \\ julianatullerm@gmail.com, elisalana00@gmail.com, laisfmaia@gmail.com, raphaelalexandremoraes@gmail.com, \\ lucasdbf@gmail.com \\ * Correspondence
}

Received 10-XI-2014. Corrected 10-V-2015. Accepted 12-VI-2015.

\begin{abstract}
Food web studies, which include qualitative and quantitative information about species interactions for all trophic levels in a specific community, are important tools to characterize the community structure, and to understand the role of species interaction in natural communities. With this aim, we collected fruits of Senegalia tenuifolia from a total of nine sites from three different areas in Minas Gerais, from June to August 2011. Fruits were collected and taken to the laboratory in special containers, to allow insect development and description. And then, we characterized the food web of insects associated with these seeds, and described interactions between these organisms and the host plant, and assessed the impact of insect attacks on seed germination with an experiment under controlled conditions. Additionally, we estimated the available NPK content and the Carbon:Nitrogen ratio in both fruits and seeds. In S. tenuifolia seeds, we have found 937 associated insects of 15 species structured in four trophic levels. We found two Bruchinae seed-feeders species: Merobruchus terani and Stator maculatopygus. We also have observed the seed-feeding hymenopteran species Allorhogas sp. 1 and Prodecatoma sp. 1, and hymenopteran parasitoids species such as Eupelmus sp.1, Lyrcus sp.1, Eurytoma sp.1, Horismenus sp.1, Chelonus sp.1, Aprostocetus sp.1, Eiphosoma sp.1 and an unidentified Pteromalinae. Considering quantitative food web metrics, our data have suggested low values of generality and high values of trophic vulnerability, besides others, which demonstrated how species interactions are specialized. The impact of seed-feeding insects on seeds was found severe and prevented their germination. Lastly, seeds contained higher NPK content than fruits. In conclusion, the seed predation food web supported by S. tenuifolia has depicted two different features: specialized species interactions, considering parasitoids and seed-feeding species, and, generalized species interactions, considering host-plant and seed-feeding species. Indeed, seeds are resources with high nutrient concentration supporting a rich and complex food web. Finally, S. tenuifolia seeds are directly impacted by seed-feeding insects, preventing them from germination, which could result in a negative effect on host-plant population. Rev. Biol. Trop. 63 (4): 1149-1159. Epub 2015 December 01.
\end{abstract}

Key words: Bruchinae, seed-feeders, host-parasitoids, insect-plant interactions, quantitative food web.

Food web studies, which focus mainly on trophic interactions, are important tools for characterizing community structure, understanding the role of species interaction and determining the influence of these interactions on observed patterns and dynamic properties of natural communities (Paine, 1992; Hall \& Raffaelli, 1991). A complete food web study should include qualitative and quantitative information about species interactions for all trophic levels in a specific community (Lewis et al., 2002). However, the effort to explore a complete food web is daunting, especially for tropical ecosystems, and an alternative approach is to focus on community subsets (Huxham, Raffaelli, \& Pike, 1995; Lewis et al., 2002). Quantitative analyses are important to distinguish important and frequent species associations from those that are casual and rare, which is not possible when considering only 
qualitative data. In this light, host-parasitoid interactions and guilds of herbivorous insect species have been shown to be good models, since the host-parasitoid interactions are strictly quantitative - i.e., the interactions can be expressed in the same units (Memmott \& Godfray, 1994; Lewis et al., 2002).

The insects associated with fruits and seeds are interesting systems to study hostparasitoid interactions, because these systems are rich and easily sampled-seed-feeders and their parasitoids are quite static, and live within seeds throughout their larval phase. In this way, we studied the interactions among fruits and seeds of the plant Senegalia tenuifolia (L.) Britton \& Rose (Fabaceae: Mimosoideae) and its associated insects.

Senegalia tenuifolia is locally known as unha-de-gato, and it is a pioneer species broadly distributed in South America (Queiroz, 2009). Other names that have been used for this species are Acacia tenuifolia (L.) Willd, Mimosa tenuifolia L., and Acacia paniculata Duss. (tropicos.org, 2011), and has been characterized as a liana (Brandes \& Barros, 2008) or as a shrub (Lima, Mansano, \& Araújo, 2012). However, the best characterization is a scandent shrub, i.e., a shrub that is able to become a liana and reach a greater height (Silva, Santos, \& Fernandes-Bulhão, 2007). Senegalia tenuifolia flowering occurs from November to January, and the fruit ripening occurs from January to August. After this phase, fruits open and seeds begin to fall on the ground.

Seeds are one of the most nutritive plant parts, because they determine the initial seedling success (Woodwell, Whittaker, \& Houghton, 1975), and, consequently seed-feeding organisms are common. Bruchinae is a beetle subfamily which feed on a single seed during their entire larval phase (Southgate, 1979). These seed-feeding interactions may directly affect plant reproduction, influencing seed fecundity and viability, and seedling establishment (Fox, Wallin, Bush, Czesak, \& Messina, 2012). Therefore, studies on interactions between seed predators and plants are essential to the development of a better understanding of community dynamics in natural habitats. Interactions between seed predators and plants may influence recruitment and, as a result, plant population dynamics (Campbell \& Clarke, 2006).

Sometimes herbivore impacts are not strongly affecting the host plant, when species at higher trophic levels, such as parasitoids, control herbivore populations (Stiling \& Rossi, 1997). Nevertheless, studies commonly ignore parasite and parasitoid species due to methodological and taxonomic difficulties in documenting their interactions (Huxham et al., 1995), or even due to the low abundance of these organisms. Hence, studies on parasites and parasitoids are mostly common in systems with economic importance (Schmale, Wäckers, Cardona, \& Dorn, 2002; Bukovinszky, Van Veen, Jongema, \& Dicke, 2008). As a result, most species associated with plants that are not economically important remain unknown to science. Assuming the source food web supported by $S$. tenuifolia and its associated insects, our goals were to: $(i)$ determine the abundance, assign the observed insect species to trophic levels and describe the quantitative food web metrics, (ii) estimate NPK content available and the Carbon:Nitrogen ratio in the fruits and seeds, and (iii) evaluate seed-feeding insect impacts on seed germination.

\section{MATERIALS AND METHODS}

Study area: We carried out our study in Lavras and Luminárias municipalities, Minas Gerais state, Southeastern Brazil (Fig. 1 SMSupplementary material). We selected three areas in the Southern region of the state where S. tenuifolia occurs: Ae, La, and Lu. Within these areas, we established nine sites, or subareas, at least $400 \mathrm{~m}$ away from each other, from where we collected $S$. tenuifolia

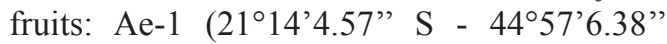
W), Ae-2 (21 $\left.1^{\circ} 14^{\prime} 5.71^{\prime \prime} \mathrm{S}-44^{\circ} 57^{\prime} 8.66^{\prime \prime} \mathrm{W}\right)$,

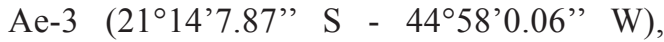
La-1 (21 ${ }^{\circ} 18^{\prime} 3.46^{\prime \prime} \mathrm{S}-44^{\circ} 58^{\prime} 0.53^{\prime}$ " W), La-2 $\left(21^{\circ} 19^{\prime} 4.85^{\prime \prime} \mathrm{S}-44^{\circ} 57^{\prime} 8.66^{\prime \prime} \mathrm{W}\right)$, Lu-1 $\left(21^{\circ} 31 ' 1.36^{\prime \prime} \mathrm{S}-44^{\circ} 53^{\prime} 1.78^{\prime}\right.$ W), Lu-2 


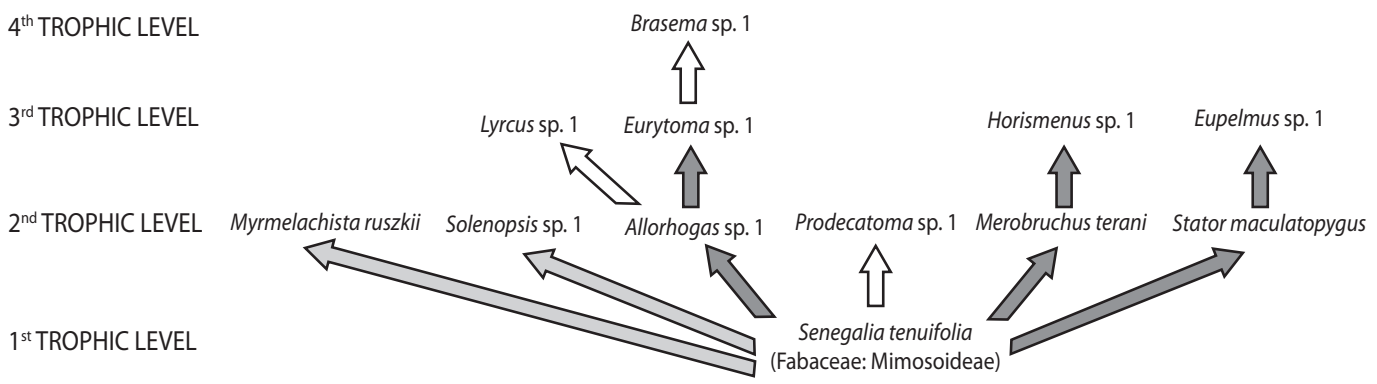

Fig. 1. The food web of insects associated with Senegalia tenuifolia fruits and their confirmed and potential trophic interactions. Insects with uncertain relationships were excluded. Black arrows represent confirmed relationships, white arrows represent potential relationships according to the literature and gray arrows represent relationships without consumption.

(2131'5.13" S - 4452'6.32" W), Lu-3 $\left(21^{\circ} 31^{\prime} 5.31^{\prime \prime} \mathrm{S}-44^{\circ} 52^{\prime} 3.84^{\prime \prime} \mathrm{W}\right)$, and $\mathrm{Lu}-4$ (2131'26.90” S - 4451'40.80” W).

These nine subareas were located at an average altitude of 900 m.a.s.l. The predominant climate in the region is highland tropical, characterized by mild summers and dry winters, the average annual temperature is $19.4^{\circ} \mathrm{C}$ and the average annual rainfall is $1530 \mathrm{~mm}$ (Sparovek, VanLier, \& Dourado-Neto, 2007). The original vegetation in the region is characterized as a seasonal forest and belongs to the Atlantic Forest domain (Veloso, Rangel-Filho, \& Lima, 1991) in transition with the Cerrado domain. The vegetation has been severely fragmented by human activities, mainly related to coffee plantations and other crops, as well as pastures. In this fragmented landscape, the studied plants can be frequently found at forest edges.

Fruits, seeds, nutrients and associated insects: From June to August 2011, we sampled eight of the subareas established for the present study (subarea Lu-4 was not included this year) three times, collecting fruits randomly from $S$. tenuifolia. In each subarea, we collected 25 fruits per sampling event, summing up 75 fruits per subarea and 600 fruits in the total. Next, we stored fruits in paper bags identified by subarea and date and took them to the laboratory for subsequent processing.
In the laboratory, we individually stored each fruit in a labeled PVC tube, sealed with voile attached with rubber bands, allowing air exchange between the tube and the laboratory. This storage allowed the complete development of insects contained in the fruits, and promoted their later emergence without loses.

After three months of storage, we analyzed fruits. First, we recorded all Bruchinae egg signal located on the surface of collected $S$. tenuifolia pods to determine egg abundances. It was not possible to identify Bruchinae eggs to species, so we recorded all eggs (without Bruchinae species identification). Next, we classified seeds as aborted (small and black), attacked (with a hole or consumed/deformed by the seed-feeding Hymenoptera, Allorhogas sp.), or apparently healthy (without any attack sign), and counted them. Based on these values, we calculated the proportion of seeds attacked (seed consumption rate).

We stored all insects found in S. tenuifolia fruits and seeds in $1.5 \mathrm{~mL}$ labeled plastic microtubes, containing $70 \%$ alcohol. Next, we morphotyped and sent them to specialists for identification. During larval phase, Bruchinae mouthpart larvae, constituted by keratin, is not absorbed by the adult beetles, parasitoid species are not also able to absorb them when parasitizing its hosts, so these materials help to identify species-specific host-parasitoid relationships. We determined these relationships between Bruchinae and parasitoids based on 
the comparison of Bruchinae larvae remaining mouthparts between those that successfully developed and those that were parasitized. We also used literature data to help us determining these relationships (Janzen, 1969; Southgate, 1979; Johnson \& Siemens, 1997; Graham, 1987; Macêdo \& Monteiro, 1989; Hanson \& Gauld, 1995; Wharton, Marsh, \& Sharkey, 1997; Marsh, Macêdo, \& Pimental, 2000; Richard , Fabre, \& Dejean , 2001; Longino, 2003, 2006; Montoya, Rodríguez, \& Hawkins, 2003; Perioto \& Lara, 2004; Perry, Mondor, \& Addicott, 2004; Morse \& Farrel, 2005; Sari \& Ribeiro-Costa, 2005; Askew \& NievesAldrey, 2006; Östergård, Hambäck, \& Ehrlén, 2007; Triana \& Ravelo, 2007; Bonet, 2008; Chavarría, Hanson, Marsh, \& Shaw, 2009; Rosumek et al., 2009; Perry et al., 2004; Fusu, 2009; Lanan, Dornhaus, \& Bronstein, 2011; Rossi, Rodrigues, Ishino, \& Kestring, 2011; Pringle, 2014).

In order to estimate nutrient availability and C:N balance of $S$. tenuifolia seeds and fruits we grounded fruits and seeds and sent them to the Laboratory of Leaf Analysis at the Federal University of Lavras for chemical analysis (NPK-nitrogen, phosphorus, and potassium). For each of the eight subareas, we classified analysis of chemical elements according to five categories: infested fruits (IF), uninfested fruits (UF), unattacked seeds of infested fruits (USIF), attacked seeds of infested fruits (ASIF), and unattacked seeds of uninfested fruits (USUF). It was not possible to analyze fruit and seed categories for each sampling event alone due to the reduced $S$. tenuifolia seed biomass. Lastly, we have estimated carbon:nitrogen ratio $(\mathrm{C}: \mathrm{N})$ for all fruit and seed categories (for more details please see Supplementary Material).

Seed germination test: In August 2012, in order to carry out germination tests, we collected $25 \mathrm{~S}$. tenuifolia fruits in each subarea, except for La-1 and Ae-1. We excluded these subareas from germination tests due to fires that occurred in September 2011 which affected these sites. Next, we stored fruits in paper bags identified by subarea and took them to the laboratory for the tests.

In the laboratory, we have set three seed germination treatments with 15 seeds $(\mathrm{N}=$ 15) each treatment and replicated each treatment three times, totalizing 135 seeds. Treatments were categorized as: unattacked seeds of infested fruits (USIF), attacked seeds of infested fruits (ASIF), and unattacked seeds of uninfested fruits (USUF). We have selected randomly 45 seeds of each category and placed each seed on an individual $9 \mathrm{~cm}$ diameter Petri dish, having as the substrate filter paper soaked with distilled water and sealed the dishes with PVC wrap. Next, we randomly placed the petri dishes with seeds of different treatments into B.O.D. incubator chamber with photophase $12: 12 \mathrm{~h}$ and constant temperature at $25^{\circ} \mathrm{C}$. Over a period of 15 days, we daily monitored germination and considered germinated seeds those that developed approximately $2 \mathrm{~mm}$ of root (Rehman, Harris, Bourne, \& Wilkin, 1996).

For data analysis, we built two generalized linear models (GLM) to compare insect species abundances belonging to second (seed-feeders) and third (primary parasitoids) trophic levels separately. We included in models only species presented in Fig. 1. In the first model, total abundance of each seed-feeding species was the response variable and seed-feeding species identity was explanatory variable. The second model was similar, but made for primary parasitoids. We also have built four GLM to compare chemical element contents and $\mathrm{C}: \mathrm{N}$ ratio between fruit and seed categories and one GLM to compare germination rates between the three categories (for more details please see supplementary material). In each model, we used the most suitable distribution, according to the data type: Gaussian distribution for continuous, Poisson for count and Binomial for percentage data (McCullagh \& Nelder, 1989). In addition, we made a contrast analysis to test differences between insect species abundance and seed categories.

Lastly, we have calculated basic quantitative food web metrics -please see Jordán and Scheuring (2004)- to our source food 
web supported by $S$. tenuifolia. The species included in the analysis are represented in the Fig. 1. It is interesting to observe that three rare hymenopteran species were excluded since we were not sure about their trophic position and links. Quantitative food web analyses were performed using R package cheddar (Hudson, 2014). All analyses were performed in the software R 2.14 (R Development Core Team, 2011).

\section{RESULTS}

We assessed a total of 598 fruits and 4352 seeds of $S$. tenuifolia. Fruits had a maximum of 14 locust seeds $(8.13 \pm 2.30)$ and 14 seeds $(7.29$ $\pm 2.64)$. Among all seeds assessed, $23.7 \%$ had been attacked, $7.8 \%$ aborted, and $68.5 \%$ were apparently healthy. Hence, $25.7 \%$ of seeds that completed their development, i.e., non-aborted seeds, had been attacked.

Insects associated with seeds and their interactions: In 598 S. tenuifolia fruits, we have found 937 associated insects of 15 species. Among these, we found two coleopteran species (708 individuals) and 13 hymenopteran species (229 individuals) (Table 1 Supplementary Material), which included two ant species (43 individuals). We found the ants Myrmelachista ruszkii (Forel, 1903) and Crematogaster sp.1, which occurred in nine fruits and had summed abundances of 34 and seven individuals, respectively.
Apart from seed-feeding adults, we counted 2192 Bruchinae eggs on fruits and found that egg abundance increased as the host plant reproductive season advanced (Table 1). Among the three most abundant seed-feeding insects, Merobruchus terani (Kingsolver, 1980) (Chrysomelidae: Bruchinae) was most abundant $(\mathrm{P}<0.001, \mathrm{~F}=17.0)$ followed by Stator maculatopygus (Chrysomelidae: Bruchinae) (Pic, 1930) and Allorhogas sp. 1 (Braconidae), which had similar abundances. Furthermore, it is interesting to notice that two Bruchinae species represented more than $90 \%$ of the total seed-feeding insect abundance, and that among parasitoids, two hymenopteran species corresponded to $85 \%$ of the total abundance of this guild. In addition, parasitoid species abundances from lowest to highest were: Eupelmus sp. 1 (Eupelmidae $)=$ Lyrcus sp. 1 (Pteromalidae) $<$ Eurytoma sp. 1 (Eurytomidae) $<$ Horismenus sp. 1 (Eulophidae) $(\mathrm{P}<0.001, \mathrm{~F}=24.0)$. In addition, in comparison to seed predators, parasitoids were rare in the system and showed low total and relative abundance (Table 1 Supplementary Material).

A summary of each species feeding habits is presented in Table 1 of the Supplementary material. Based on the feeding habits listed in Table 1SM, we constructed a diagram with probable feeding interactions of insects associated with $S$. tenuifolia fruits (Fig. 1). Species with uncertain relationships were not included in Fig. 1. Considering the food web depicted at

TABLE 1

Abundance of eggs of seed-feeding Bruchinae laid on pods of Senegalia tenuifolia in the region of Lavras, Southeastern Brazil

\begin{tabular}{ccccc}
\hline Subarea & \multicolumn{3}{c}{ Sampling } & Total \\
\hline La-1 & June 2011 & July 2011 & August 2011 & 197 \\
La-2 & 115 & 40 & 42 & 183 \\
Ae-1 & 49 & 74 & 60 & 304 \\
Ae-2 & 121 & 80 & 103 & 263 \\
Ae-3 & 64 & 88 & 111 & 608 \\
Lu-1 & 142 & 204 & 262 & 282 \\
Lu-2 & 88 & 93 & 101 & 82 \\
Lu-3 & 10 & 23 & 49 & 273 \\
Total & 51 & 60 & 162 & 2192 \\
\hline
\end{tabular}




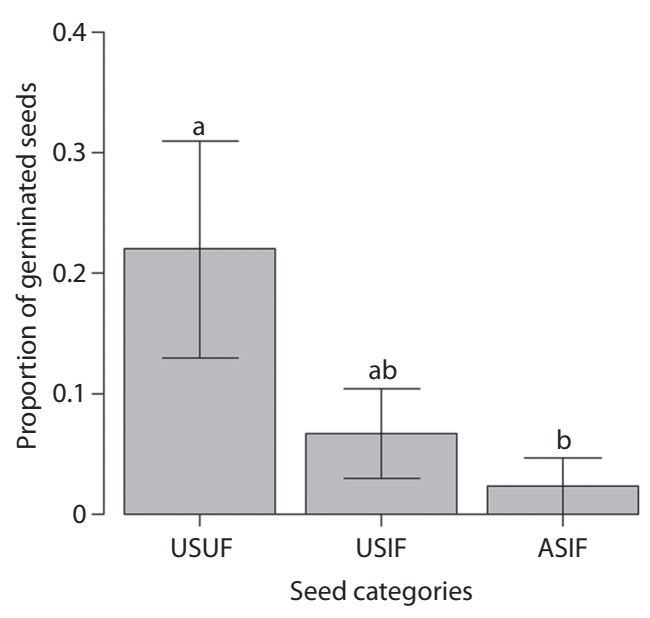

Fig. 2. Proportion of different categories of Senegalia tenuifolia germinated seeds in the region of Lavras, Southeastern Brazil. USUF $=$ unattacked seed of an uninfested fruit, USIF = unattacked seed of an infested fruit, and ASIF = attacked seed of an infested fruit. Different letters represent statistically distinct categories.

Fig. 1, quantitative food web metrics were estimated as follow: 12 species or nodes $(S)$, linkage density of $0.92(L S), 0.08$ of connectance $(C)$, proportion of basal, intermediate and top species of $0.08,0.33$ and 0.58 respectively, 2.20 of predator-prey ratio, 1.00 and 2.20 of trophic generality and trophic vulnerability respectively, and lastly, an average chain length of 0.76 .

Nutrient availability and $C: N$ balance of Senegalia tenuifolia seeds and fruits: As general outcomes, chemical analyses have suggested seeds had higher nutrient contents than fruits. Both infested fruits and attacked seeds tended to have a higher $\mathrm{P}$ and $\mathrm{K}$ contents than uninfested fruits and unattacked seeds. In respect to $\mathrm{C}: \mathrm{N}$ ratio, fruits depicted eight times higher ratio than seeds, however, when considering both fruit categories and three seed categories the $\mathrm{C}: \mathrm{N}$ ratio were similar. Further, despite the $\mathrm{C}: \mathrm{N}$ ratio importance to live organisms, it did not influence the associated insects richness. Nutrients availability and $\mathrm{C}: \mathrm{N}$ balance have suggested no connection to any of the seed predator data so we have decided to include the details as supplementary material, including statistical test and figures.
Germination test of Senegalia tenuifolia seeds: Of the 135 seeds of $S$. tenuifolia that we tested, 15 germinated $(11.11 \%)$. Among these, ten belonged to the seed category USUF, four to USIF, and only one to ASIF. Seed germination rates were ranked as follows: USUF > USIF > ASIF. However, the germination rate differed significantly only between USUF and ASIF seed categories ( $\mathrm{P}=0.043, \mathrm{~F}=6.6$, Fig. 2). Despite this, we observed lower germination rate in both seed categories that came from infested fruits (USIF and ASIF) compared to seeds of uninfested fruits (Fig. 2). Therefore, S. tenuifolia seed consumption by insects has a direct negative effect on seed germination through ASIF seeds.

\section{DISCUSSION}

In the studied food web, associated with $S$. tenuifolia seeds, we found 15 different insect species, spanning three trophic levels: seed-predating insects and their primary and secondary parasitoids. This food web is a relatively complex system composed of three compartmentalized subwebs involving two Bruchinae species and Allorhogas sp. 1, and their parasitoids. The attacks by seed-predating insects were influenced by chemical seed and fruit characteristics, at the same time seeds had lower C:N ratio than fruits. Further, seed-feeding insects of the Bruchinae subfamily had a negative effect on $S$. tenuifolia seed germination.

Among all food web species, seed-predating Bruchinae were the two most abundant species, with Merobruchus terani being eight times more abundant than Stator maculatopygus. Seed-predating Bruchinae, such as those found in the present study, spend their entire larval phase feeding within seeds (Southgate, 1979) and are very common in the Fabaceae family (Janzen, 1969; Southgate, 1979; Östergård et al., 2007; Rossi et al., 2011). The beetles $M$. terani and $S$. maculatopygus attack seeds throughout the reproductive season, and we observed the highest Bruchinae egg abundances at the end of Senegalia tenuifolia reproductive season. Merobruchus terani 
attacks fruits while they are still attached to the mother-plant, and only one Bruchinae individual develops inside each seed (Johnson \& Siemens, 1997). Merobruchus terani is considered a specialist on Acacia (Johnson \& Siemens, 1997). Stator maculatopygus has previously been reported consuming Senegalia bonariensis (Gillies ex Hook. \& Arn.) Seigler \& Ebinger seeds, and was described as having the habit of ovipositing directly into dispersed fruits - i.e., secondary predation (Morse \& Farrel, 2005). However, we found all the $S$. maculatopygus individuals in S. tenuifolia pre-dispersed fruits.

We also observed a braconid, Allorhogas sp. 1 as a $S$. tenuifolia seed predator. According to the literature, this genus is exclusively composed of seed-predating and gall-inducing insects (Marsh et al., 2000; Chavarría et al., 2009). In S. tenuifolia, Allorhogas sp.1 feeds from the extremities, causing deformities in developing seeds. Each seed may contain one or several individuals, similar to Allorhogas species observed by Macêdo and Monteiro (1989). We also found a Prodecatoma (Braconidae) individual, species of this genus have been found in fruits and seeds of several families, among them Fabaceae (Perioto \& Lara, 2004).

Among primary parasitoids, the most abundant was Horismenus sp.1 (Eulophidae), which was identified as a Bruchinae Merobruchus terani parasitoid. In the present study, we found one Eupelmus species, which is a Bruchinae Stator maculatopygus parasitoid. According to the literature, Eupelmus are coleopteran larvae and pupae ectoparasitoids (Fusu, 2009) and may also be Bruchinae parasitoids (Sari \& Ribeiro-Costa, 2005; Bonet, 2008). One Pteromalinae species that occurred only once into the collected fruit and was not identified may be a Bruchinae larvae parasitoid or even a hyperparasitoid (Hanson \& Gauld, 1995). Lyrcus was another genus found, of which only one species has been cited as a possible Allorhogas parasitoid (Marsh et al., 2000).

We found Eurytoma sp. 1 located at seed extremities attacked by Allorhogas sp.1, and suggest that it is a parasitoid on seed-predating hymenoptera. This is supported by Eurytoma species classification as Allorhogas larval ectoparasites by several authors (Macêdo \& Monteiro, 1989; Marsh et al., 2000). An interesting component of the studied food web is the hymenopteran Brasema sp.1. Insects of this genus can be Eurytoma parasites (Askew \& Nieves-Aldrey, 2006). Therefore, if the Brase$m a$ species found in S. tenuifolia is Eurytoma sp.1 parasitoid, then it is a secondary parasitoid. We also observed another possible secondary parasitoid: Aprostocetus sp.1 (Eulophidae: Tetrastichinae), a genus that comprises egg parasitoids and hyperparasitoids of several insect orders, including hymenopterans of the genus Eurytoma (Graham, 1987). Higher hyperparasitism occurrences in a system decrease parasitism and herbivore mortality rates (Montoya et al., 2003). It may suggest a top-down cascade effect releasing herbivorous species to consume seeds, so increasing the impact on S. tenuifolia.

Due to their low abundance, it was not possible to determine relationships of some insects within the studied food web. We found insects of the genus Chelonus, which is usually a lepidopteran parasitoid (Wharton et al., 1997), as is the genus Eiphosoma (Triana \& Ravelo, 2007). Hence, the absence of lepidopterans from the collected insects explains the very low abundance of these parasitoids.

We also found two ant species, Myrmelachista ruszkii (Longino, 2006) and Crematogaster sp. (Longino, 2003), which belong to exclusively arboreal genera. Frequently, Crematogaster species are observed forming small satellite colonies on plants to keep themselves close to ephemeral food sources, such as extrafloral nectaries (Lanan et al., 2011), organs that are present on the studied plant species. Some studies have detected a positive effect of ants on plants (Rosumek et al., 2009), frequently because ants play an indirect defense role, driving off organisms that could feed on the host plant's seeds (Perry et al., 2004; Pringle, 2014). Thus, M. ruszkii and Crematogaster sp. may be using $S$. tenuifolia fruits as a shelter, protecting fruits from attacks by seed-feeders, since $\mathrm{Cre}$ matogaster ants are very aggressive (Richard et al., 2001; Longino, 2003). 
After we excluded three hymenopteran species by lacking robustness on trophic position and links, structural source food web were described in respect to quantitative metrics to better understand it. We have found striking differences between $S$. tenuifolia data and the results presented by Tylianakis, Tscharntke and Lewis (2007). Most of our estimated metrics showed lower values, except trophic vulnerability. It reveals how simple our seed predation food web is. Further, considering the hostparasitoid species specificity here ascribed, source seed predation food web supported by $S$. tenuifolia has a higher vulnerability to secondary extinction. In respect to connectance, our results showed similar values to those observed in other food webs (Dunne, 2006; Tylianakis et al., 2007), corroborating with Martinez's idea (1992) in which connectance values are likely to be similar throughout natural food webs.

Chemical analysis carried out with different fruit and seed categories revealed a pattern of higher nitrogen, phosphorus, and potassium content in $S$. tenuifolia seeds than in fruits. Higher NPK content is essential for insects which feed on a single seed during their whole larval phase. Then, seed-feeding strategy may have advantage in terms of limiting factor such as nitrogen (Huberty \& Denno, 2006). Further, this kind of resource - e.g., seeds - can support a complex food web composed by different species and interactions as observed here.

Based on the germination test carried out in 2012, we observed that $S$. tenuifolia seeds attacked by insects had reduced germination rates. This reduction happens because seed consumption by insects at the ripening phase makes seeds hollow and destroys their germination potential (Scherer \& Romanowski, 2005). Another relevant factor is that seed predators frequently kill the embryo or remove part of the seed endosperm, which makes germination impossible (Southgate, 1979; Tomaz, Kestring, \& Rossi, 2007; Fox et al., 2012).

The present study shows that resources with high nutrient concentration, such as seeds, may sustain a relatively complex food web, involving species of several taxonomic groups and trophic levels. In addition, based on the natural history of involved species and their roles in the food web, this system is an interesting case for the study of complex ecological interactions and their structural and functional patterns. The structural characterization of the source food web of insects associated with Senegalia tenuifolia seeds showed an interspecific interaction frequency with few species presenting high interaction frequencies and strong interaction strength, but most species presenting low interaction frequency and weak interaction strength. This food web is complex, it is unravelling through the direct and indirect relationship explorations among different trophic level species will advance our understanding of interaction ecology.

\section{ACKNOWLEDGMENTS}

C. S. Ribeiro-Costa, A. R. Nascimento, A. C. M. de Queiroz, and M. S. C. Morin helped us in insect identification. The Federal University of Lavras and the Graduate School in Applied Ecology gave us logistic support. The Minas Gerais Research Foundation (FAPEMIG) funded the present study and granted Lais F. Maia and Raphael A. Moraes undergraduate scholarships. The Brazilian National Council for Scientific and Technological Development (CNPq) granted Elisa L. de Paula an undergraduate scholarship. The Brazilian Coordination for the Improvement of Higher Education Personnel (CAPES) granted Juliana Tuller a Masters scholarship. Lucas D. B. Faria thanks FAPEMIG and CNPq for their financial support.

\section{RESUMEN}

Red alimentaria de depredación de semillas, disponibilidad de nutrientes e impacto sobre la germinación de las semillas de Senegalia tenuifolia (Fabaceae). Estudios de redes alimentarias, que incluyen información cualitativa y cuantitativa sobre las interacciones entre especies para todos los niveles tróficos en una comunidad específica, son herramientas importantes para caracterizar la estructura de la comunidad, y para comprender el papel de la interacción de las especies en las comunidades 
naturales. Con este objetivo, se recolectaron frutos de Senegalia tenuifolia de un total de nueve sitios de tres áreas diferentes, en Minas Gerais, entre junio y agosto 2011. Los frutos fueron recolectados y llevados al laboratorio en contenedores especiales, para permitir el desarrollo y descripción del insecto. Luego, se caracterizó la red alimentaria de los insectos asociados a estas semillas, se describieron las interacciones entre estos organismos y la planta hospedera, y se evaluó el impacto del ataque de insectos en la germinación de semillas mediante un experimento en condiciones controladas. Además, se estimó el contenido de NPK y la relación carbono:nitrógeno en frutos y en semillas. En semillas de S. tenuifolia, se encontraron 937 insectos de 15 especies estructuradas en cuatro niveles tróficos. Se encontraron dos especies de Bruchinae que se alimentan de semillas: Merobruchus terani y Stator maculatopygus. También se observaron especies de himenópteros que se alimentan de semillas: Allorhogas sp. 1 y Prodecatoma sp. 1, y especies de himenópteros parasitoides como: Eupelmus sp.1, Lyrcus sp.1, Eurytoma sp.1, Horismenus sp.1, Chelonus sp.1, Aprostocetus sp.1, Eiphosoma sp.1 y un Pteromalinae no identificado. Nuestros datos sugieren valores bajos de generalidad trófica y valores altos de vulnerabilidad trófica, además de otros, lo que demuestra cómo las interacciones entre especies son especializadas. El impacto en las semillas de los insectos que se alimentan de estas es severo e impidió su germinación. Por último, las semillas tenían un mayor contenido de NPK que los frutos. En conclusión, la red alimentaria de depredación de semillas con $S$. tenuifolia tiene dos características: interacciones de especies especializadas, considerando parasitoides y especies comedoras de semillas, e interacciones generalizadas entre especies, teniendo en cuenta la planta hospedera y las especies comedoras de semillas. De hecho, las semillas son recursos con alta concentración de nutrientes que proveen una rica y compleja red trófica. Por último, las semillas de $S$. tenuifolia se ven directamente afectadas por los insectos que se alimentan de semillas, que les impide la germinación, lo que podría resultar en un efecto negativo en la población planta-hospedero.

Palabras clave: Bruchinae, comedores de semillas, hospedero-parasitoides, interacción planta-insecto, cuantificación de redes alimentarias.

\section{REFERENCES}

Askew, R. R., \& Nieves-Aldrey, J. L. (2006). Calosotinae and Neanastatinae in the Iberian Peninsula and Canary Islands, with descriptions of new species and a supplementary note on Brasema Cameron, 1884 (Hymenoptera, Chalcidoidea, Eupelmidae). Graellsia, 62(1), 87-100.

Bonet, A. (2008). New hosts, host plants, and distribution records for Horismenus (Hymenoptera: Eulophidae) species in a bruchid beetle parasitoid guild attacking wild type Phaseolus coccineus and P. vulgaris in Central Mexico. Florida Entomologist, 91(4), 698-701.

Brandes, A. F. N., \& Barros, C. F. (2008). Anatomia do lenho de oito espécies de lianas da família Leguminosae ocorrentes na Floresta Atlântica [Wood anatomy of eight liana species of Leguminosae family from Atlantic Rain Forest] Portuguese. Acta Botanica Brasílica, 22(2), 465-480.

Bukovinszky, T., Van Veen, F. J. F., Jongema, Y., \& Dicke, M. (2008). Direct and indirect effects of resource quality on food web structure. Science, 319, 804-807.

Campbell, M. L., \& Clarke, P. J. (2006). Seed dynamics of resprouting shrubs in grassy woodlands: Seed rain, predators and seed loss constrain recruitment potential Austral Ecology, 31, 1016-1026.

Chavarría, L., Hanson, P., Marsh, P., \& Shaw, S. (2009). A phytophagous braconid, Allorhogas conostegia sp. nov. (Hymenoptera: Braconidae), in the fruits of Conostegia xalapensis (Bonpl.) D. Don (Melastomataceae). Journal of Natural History, 43(43), 2677-2689.

Dunne, J. A. (2006). The network structure of food webs. In M. Pascual \& J. A. Dunne (Eds.), Ecological networks: Linking structure to dynamics in food webs (pp. 27-86). New York: Oxford University Press.

Fox, C. W., Wallin, W. G., Bush, M. L., Czesak, M. E., \& Messina, F. J. (2012). Effects of seed beetles on the performance of desert legumes depend on host species, plant stage, and beetle density. Journal of Arid Environment, 80, 10-16.

Fusu, L. (2009). Romanian Eupelmidae (Hymenoptera, Chalcidoidea): new cytogenetic, faunistic and host records. North-Western Journal of Zoology, 5(2), 307-320.

Graham, M. W. R. V. (1987). A reclassification of the European Tetrastichinae (Hymenoptera: Eulophidae), with a revision of certain genera. Bulletin of the British Museum (Natural History - Entomology Series), 55(1), 1-392.

Hall, S. J., \& Raffaelli, D. (1991). Food-web patterns: Lessons from a species-rich web. Journal of Animal Ecology, 60(3), 823-841.

Hanson, P. E., \& Gauld, I. D. (1995). The Hymenoptera of Costa Rica. Oxford: Oxford University Press.

Hudson, L. (2014). cheddar: Analysis and visualization of ecological communities. R package version 1.14.

Huberty, A. F., \& Denno, R. F. (2006). Consequences of nitrogen and phosphorus limitation for the performance of two planthoppers with divergent life-history strategies. Oecologia, 149, 444-455.

Huxham, M., Raffaelli, D., \& Pike, A. (1995). Parasites and food web patterns. Journal of Animal Ecology, 64,168-176. 
Janzen, D. H. (1969). Seed-eaters versus seed size, number, toxicity and dispersal. Evolution, 23(1), 1-27.

Johnson, C. D., \& Siemens, D. H. (1997). Oviposition behavior, guilds, host relationships and new host and distribution records for the genus Merobruchus Bridwell (Coleoptera: Bruchidae). Coleopteran Bulletin, 51(1), 13-21.

Jordán, F., \& Scheuring, I. (2004). Network ecology: topological constraints on ecosystem dynamics. Physics of Life Reviews, 1, 139-172.

Lanan, M. C., Dornhaus, A., \& Bronstein, J. L. (2011). The function of polydomy: The ant Crematogaster torosa preferentially forms new nests near food sources and fortifies outstations. Behavioral Ecology and Sociobiology, 65, 959-968.

Lewis, O. T., Memmott, J., Lasalle, J., Lyal, C. H. C., Whitefoord, C., \& Godfray, H. C. J. (2002). Structure of a diverse tropical forest insect-parasitoid community. Journal of Animal Ecology, 71, 855-873.

Lima, J. R., Mansano, V. F., \& Araújo, F. S. (2012). Coexistence and geographical distribution of Leguminosae in an area of Atlantic forest in the semi-arid region of Brazil. Journal of Systematics and Evolution, 50(1), 25-35.

Longino, J. T. (2003). The Crematogaster (Hymenoptera, Formicidae, Myrmicinae) of Costa Rica. Zootaxa, $151,1-150$

Longino, J. T. (2006). A taxonomic review of the genus Myrmelachista (Hymenoptera: Formicidae) in Costa Rica. Zootaxa, 1141, 1-54.

Macêdo, M. V., \& Monteiro, R. F. (1989). Seed predation by a braconid wasp, Allorhogas sp. (Hymenoptera). Journal of the New York Entomological Society, 97(3), 358-362.

Marsh, P. M., Macêdo, M. V., \& Pimental, M. C. P. (2000). Descriptions and biological notes on two new phytophagous species of the genus Allorhogas from Brazil (Hymenoptera: Braconidae: Doryctinae). Journal of Hymenopteran Research, 9(20), 292-297.

Martinez, N. D. (1992). Constant connectance in community food webs. American Naturalist, 139(6), 1208-1218.

McCullagh, P. \& Nelder, J. A. (1989). Generalized Linear Models. 2 ed. New York: Chapman and Hall.

Memmott, J., \& Godfray, H. C. J. (1994). The use and construction of parasitoids webs. En B. A. Hawkins \& W. Sheehan (Eds.), Parasitoid Community Ecology (pp. 3300-3318). Oxford: Oxford University Press.

Montoya, J. M., Rodríguez, M. A., \& Hawkins, B. A. (2003). Food web complexity and higher-level ecosystem services. Ecology Letters, 6, 587-593.

Morse, G. E., \& Farrell, B. D. (2005). Ecological and evolutionary diversification of the seed beetle genus
Stator (Coleoptera: Chrysomelidae: Bruchinae). Evolution, 59(6), 1315-1333.

Östergård, H., Hambäck, P. A., \& Ehrlén, J. (2007). Predispersal seed predation: the role of fruit abortion and selective oviposition. Ecology, 88(12), 2959-2965.

Paine, R. T. (1992). Food web analysis through field measurement of per capita interaction strength. Nature, $355,73-75$.

Perioto, N. W., \& Lara, R. I. R. (2004). Revisão da bibliografia do gênero Prodecatoma Ashmead, 1904 (Hymenoptera, Chalcidoidea, Eurytomidae). Arquivos do Instituto de Biologia, 71(1), 133-135.

Perry, J. C., Mondor, E. B., \& Addicott, J. F. (2004). An indirect mutualism: ants deter seed predators from ovipositing in yucca fruit. Canadian Journal of Zoology, 82, 823-827.

Pringle, E. G. (2014). Harnessing ant defence at fruits reduces bruchid seed predation in a symbiotic antplant mutualistim. Proceedings of the Royal Society Biology, 281, 1-7.

Queiroz, L. P. (2009). Leguminosas da Caatinga. Universidade Estadual de Feira de Santana: Feira de Santana.

$\mathrm{R}$ development core team 2.14. (2011). R: a language and environment for statistical computing. Vienna: $\mathrm{R}$ Foundation for Statistical Computing. Retrieved from http://www.rproject.org

Rehman, S., Harris, P. J. C., Bourne, W. F., \& Wilkin, J. (1996). The effects of sodium chloride on germination and the potassium and calcium contents of Acacia seeds. Seed Science Technology, 25, 45-57.

Richard, F. J., Fabre, A., \& Dejean, A. (2001). Predatory behavior in dominant arboreal ant species: The case of Crematogaster sp. (Hymenoptera: Formicidae). Journal of Insect Behavior, 14(2), 271-282.

Rossi, M. N., Rodrigues, L. M. S., Ishino, M. N., \& Kestring, D. (2011). Oviposition pattern and withinseason spatial and temporal variation of pre-dispersal seed predation in a population of Mimosa bimucronata trees. Arthropod-Plant Interactions, 5, 1-9.

Rosumek, F. B., Silveira, F. A. O., Neves, F. S., Barbosa, N. P. U., Diniz, L., Oki, Y, Pezzini, F., Fernandes, G. W., \& Cornelissen, T. (2009). Ants on plants: a metaanalysis of the role of ants as plant biotic defenses. Oecologia, 260, 537-549.

Sari, L. T., \& Ribeiro-Costa, C. S. (2005). Predação de sementes de Senna multijuga (Rich.) H.S. Irwin \& Barneby (Caesalpinaceae) por bruquíneos (Coleoptera: Chrysomelidae). Neotropical Entomology, 34(3), 521-525.

Scherer, K. Z., \& Romanowski, H. P. (2005). Predação de Megacerus baeri (Pic, 1934) (Coleoptera: Bruchidae) sobre sementes de Ipomoea imperati (Convolvulaceae), na praia da Joaquina, Florianópolis, sul do Brasil. Biotemas, 18(1), 39-55. 
Schmale, I., Wäckers, F. L., Cardona, C., \& Dorn, S. (2002). Field infestation of Phaseolus vulgaris by Acanthoscelides obtectus (Coleoptera: Bruchidae), parasitoid abundance, and consequences for storage pest control. Environmental Entomology, 31(5), 859-863.

Silva, E. F., Santos, T. R. R., \& Fernandes-Bulhão, C. (2007). Levantamento florístico das lianas lenhosas, arbustos e subarbustos do Cerrado do Parque do Bacaba, Nova Xavantina-MT. Revista Brasileira de Biociências, 5(2), 948-950.

Southgate, B. J. (1979). Biology of the Bruchidae. Annual Review of Entomology, 24, 449-473.

Sparovek, G., VanLier, Q. J., \& Dourado-Neto, D. (2007). Computer assisted Koeppen climate classification: a case study for Brazil. International Journal of Climatology, 2, 257-266.

Stiling, P., \& Rossi, A. M. (1997). Experimental manipulations of top-down and bottom-up factors in a tritrophic system. Ecology, 78(5), 1602-1606.

Tomaz, C. A., Kestring, D., \& Rossi, M. N. (2007). Effects of the seed predator Acanthoscelides schrankiae on viability of its host plant Mimosa bimucronata. Biological Research, 40, 281-290.

Triana, J. L. F., \& Ravelo, H. G. (2007). A taxonomic review of Cuban Eiphosoma Cresson (Hymenoptera, Ichneumonidae), with biogeographical notes. Zoota$x a, 1655,49-61$.

Tylianakis, J. M., Tscharntke, T., \& Lewis O. T. (2007). Habitat modification alters the structure of tropical host-parasitoid food webs. Nature, 445, 202-205.

Veloso, H. P., Rangel-Filho, A. L. R., \& Lima, J. C. A. (1991). Classificação da vegetação brasileira adaptada a um sistema universal. Rio de Janeiro: Instituto Brasileiro de Geografia e Estatística (IBGE).

Wharton, R. A., Marsh, P. M., \& Sharkey, M. J. (1997). Manual of the New World Genera of the family Braconidae (Hymenoptera). Special Publication of the International Society of Hymenopterists, no. 1.

Woodwell, G. M., Whittaker, R. H., \& Houghton, R. A. (1975). Nutrient concentrations in plants in the Brookhaven oak-pine forest. Ecology, 56(2), 318-332. 
